\title{
Power Sizing Techniquefora 24 Hours Unceasing Grid-Connected Photovoltaic Power Plant Design based on Real World Data
}

\author{
Syafrudin Masri ${ }^{1}$, Paaventhan Raj ${ }^{2}$ \\ Associate Professor, School of EEE, UniversitiSains Malaysia, Nibong Tebal, Pulau Pinang, Malaysia ${ }^{1}$ \\ Post Graduate, School of EEE, UniversitiSains Malaysia, Nibong Tebal, Pulau Pinang, Malaysia ${ }^{2}$
}

\begin{abstract}
In this paper, a step-by-step approach of planning, designing and optimization of an unceasing single-phase grid-connected photovoltaic power plant based on real world conditions is shown. The power plant design is for a system that works continuously for all 24 hours in order to deliver continuous supply to the grid. This is due to compensate the usage throughout the day. The location of the real world climate condition chosen from is School of Electrical and Electronic Engineering, UniversitiSains Malaysia, NibongTebal, Pulau Pinang. The content includes the interpretation and tabulation of the power demand and environmental factors to develop proper technical approach to power sizing for generation based on data derived from a weather station at research location, choice of control method for the control module which includes implementing the Multiple Power Point Tracking (MPPT) technique through the power converters and also a system with very little power losses as it is delivered to the grid. The design is then proven by simulation using MATLAB/Simulink software.
\end{abstract}

Keywords: Switch, Transient, Power Quality, Grid-Connected, Photovoltaic Power Plant, Solar, Converter, Filter, Switching, Capacitor Bank.

\section{INTRODUCTION}

The interest for renewable energy has been driven by In order to support such extensive ever growing energy scope of variables like fuel price spikes, environmental demand, implementation of distributed generation will aid change concerns, public discernment, and movements in greatly in tackling this matter. Clean energy that can be renewable energy developments [1] [2]. In this edge of generated to compensate the consumption of energy at subject, the solar powered photovoltaic (PV) energy has residential households is currently being welcomed gladly. grabbed a stature of value for its low natural impact, long working time and calm operation.

The PV application is extending exponentially in the renewable energy market. It is additionally utilized today as a critical bit of innovation in different applications relating to the renewable energy era. In spite of the fact that PV modules for the most part have low effectiveness. The general PV module power inefficiency can be reduced by utilizing high ampleness power conditioners which are required to get the most conceivable level of power from the PV module.

It stated that electricity consumption for Peninsular Malaysia reached an all-time high of $17,788 \mathrm{MW}$ on the 20th of April 2016. The IEA gauges that, in 2013, all out world energy utilization was 9,301 Mtoe, equivalent to an average power consumption of 12.3 terawatts. [3] From 2000-2012 coal was the wellspring of energy with the biggest development. The utilization of oil and regular gas additionally had extensive development, trailed by hydro power and renewable energy. Renewable energy developed at a rate larger than ever in history amid this period, which can be clarified by an expansion in worldwide interest in renewable energy.

This is due to the fact that introducing distributed generation to be connected to grid will ensure the cost of setting up new power plants and additional transmission grids can be diminished. The best renewable energy source to be used in Malaysia will be solar power due to daily constant sun hours all year long.

Keeping in mind the end goal to set up an appropriate PV power plant as to real world conditions. The chosen region of set up for this specific power plant is established at the School of Electrical and Electronic Engineering, Universiti Sains Malaysia, NibongTebal, Pulau Pinang.

Actual real time data based natural information have be recorded in intervals of every 1 minute throughout the day. This will guarantee the displayed simulation results will be precise according to the environmental parameters.

This paper explains an efficient planning method to set up an unceasing power generation framework which is directly impacted by change of parameters due to climate and weather factors. It is designed to compensate the energy usage of a household throughout a day. 


\section{IJIREEICE \\ International Journal of Innovative Research in Electrical, Electronics, Instrumentation and Control Engineering ISO 3297:2007 Certified \\ Vol. 4, Issue 10, October 2016}

\section{ENVIRONMENTAL DATA ACQUISITION AND ADAPTATION}

An A weather station was set up at School of Electrical and Electronics Engineering, Universiti Sains Malaysia, NibongTebal, Pulau Pinang. The weather station has the ability to record solar activities that are very pertinent for solar powered energy generation and related researches. The weather station can be used to read, record and temperature, UV radiation, wind speed, wind direction, indoor and outdoor humidity, atmospheric pressure and solar radiation. In the scope of our station, it caters to diversified academic levels such as for undergraduate students undergoing final year projects, postgraduate students for their research works, lecturers and researchers. Establishing this station will ensure the need to rely on other external parties for meteorological data diminished. This will save both time and costing. The two pertinent data collected from the weather station related to this research is the temperature and solar radiation. Both parameters were collected for a week with varying weather patterns to get the most appropriate average values.

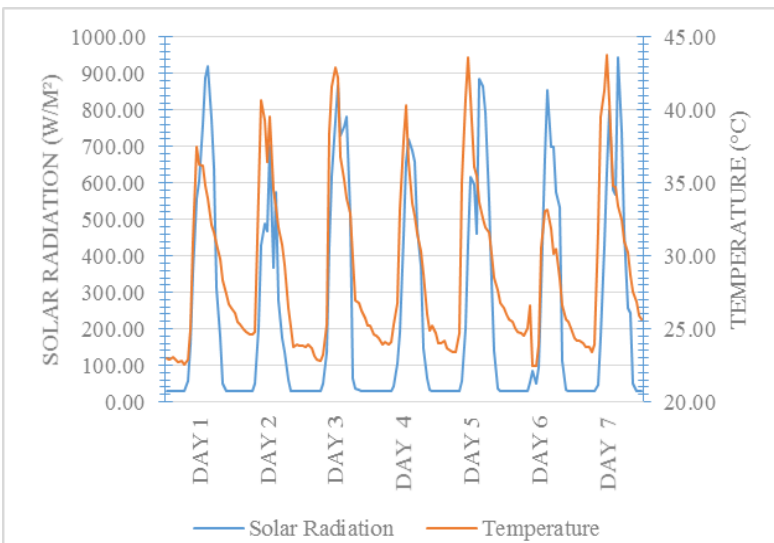

Fig. 1a Solar Radiation and Temperature Pattern for 7 days

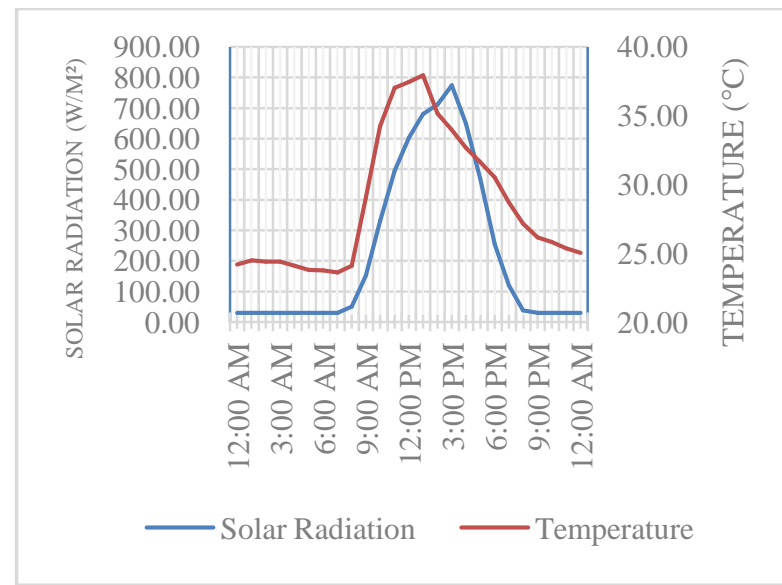

Fig. 2b Solar Radiation and Temperature Pattern for 7 days
The data is acquired with the interval of 1 minute throughout the entire week. This is done in order to get the best average and precise weather pattern. Figure 1 below shows the weather pattern for the entire 7 days data was taken and its daily average.

Based on the figures above, we can use the tabulated data as our simulation parameters. These parameters will provide a pattern to be used as varying parameters for the simulation.

\section{III.PV POWER PLANT SIZING}

The daily average of electrical consumption of a household is $8.4 \mathrm{kWh}$ [4] Although it is an unceasing system, total hours of generation per day will be 7 hours due to the average sun hours. This is due to the system being a floating system where the plant will only generate power when the voltage through the MPPT meets the boost converter input voltage to accommodate efficient duty cycle.

The input voltage of the boost converter is estimated to be met during the average sun hours. Thus instantaneous output, Pout at any given time that must be at least meeting the input voltage of the boost converter is:

$$
\begin{gathered}
\text { Pout }=8400 \mathrm{Wh} / 7 \mathrm{~h} \\
\text { Pout }=1200 \mathrm{~W}
\end{gathered}
$$

PV array in terms of parallel and series connection play an important role. The series-connected module reflect the voltage generated by the array and the parallel-connected module reflects the current produced by the array.

An equation to find the number of series-connected, parallel-connected module can be developed by this equation.

$$
(\mathrm{X} \times \mathrm{VPV}) \times(\mathrm{Y} \times \mathrm{IPV})=1200
$$

Where $\mathrm{X}$ is the Series-connected module, $\mathrm{Y}$ is the Parallelconnected module, VPV is the Maximum voltage at PV and IPV is the Maximum current at PV

In order to find the VPV and IPV, the Current - Voltage Curve based on average solar radiation and temperature must be analysed. The meteorological data collected from the weather station is used to find the aver-age solar radiation and temperature. Table 1 shows the solar radiation data and its daily average; The baseline for sun hours is chosen at $400 \mathrm{~W} / \mathrm{m}^{2}$ due to developing a Photovoltaic Power Plant that can function in conditions of $40 \%$ of peak solar irradiation. This is due to the reason of $40 \%$ of peak solar irradiation still gives a $94 \%$ of MPPT voltage of peak solar irradiation that is $25 \mathrm{~V}$.

Any lesser solar irradiation chosen will bring to the problem of not meeting minimum Boost Converter input voltage rating. 


\section{International Journal of Innovative Research in Electrical, Electronics, Instrumentation and Control Engineering ISO 3297:2007 Certified \\ Vol. 4, Issue 10, October 2016}

TABLE I Solar Radiation Data and its Daily Average

\begin{tabular}{|c|c|c|c|c|c|c|c|c|}
\hline \multicolumn{7}{|c|}{ Solar Radiation $\left(\mathrm{W} / \mathrm{m}^{2}\right)$} \\
\hline Time & Day 1 & Day 2 & Day 3 & Day 4 & Day 5 & Day 6 & Day 7 $\begin{array}{c}\text { Average } \\
\text { according } \\
\text { to hour }\end{array}$ \\
\hline 1:00 AM & 29.28 & 28.93 & 29.42 & 29.30 & 29.25 & 29.22 & 29.30 & 29.24 \\
\hline 2:00 AM & 29.20 & 28.88 & 29.32 & 29.38 & 29.27 & 29.25 & 29.32 & 29.23 \\
\hline 3:00 AM & 29.22 & 29.00 & 29.33 & 29.47 & 29.27 & 29.20 & 29.42 & 29.27 \\
\hline 4:00 AM & 29.33 & 28.92 & 29.40 & 29.32 & 29.28 & 29.25 & 29.48 & 29.28 \\
\hline 5:00 AM & 29.17 & 28.98 & 29.47 & 29.40 & 29.35 & 29.28 & 29.40 & 29.29 \\
\hline 6:00 AM & 29.22 & 28.97 & 29.42 & 29.45 & 29.23 & 29.23 & 29.50 & 29.29 \\
\hline 7:00 AM & 29.22 & 28.87 & 29.42 & 29.37 & 29.23 & 29.15 & 29.37 & 29.23 \\
\hline 8:00 AM & 55.67 & 49.03 & 49.15 & 42.32 & 55.43 & 53.30 & 47.83 & 50.39 \\
\hline 9:00 AM & 156.53 & 204.35 & 135.87 & 105.02 & 202.02 & 84.18 & 179.03 & 152.43 \\
\hline 10:00 AM & 355.00 & 428.87 & 426.27 & 190.68 & 432.70 & 50.23 & 427.15 & 330.13 \\
\hline 11:00 AM & 557.93 & 488.87 & 618.33 & 453.28 & 615.40 & 96.38 & 630.37 & 494.37 \\
\hline 12:00 PM & 606.05 & 467.20 & 772.15 & 659.20 & 597.03 & 312.80 & 800.32 & 602.11 \\
\hline 1:00 PM & 762.77 & 703.17 & 870.10 & 721.30 & 459.68 & 666.95 & 580.87 & 680.69 \\
\hline 2:00 PM & 887.83 & 366.00 & 729.20 & 688.95 & 885.40 & 853.20 & 569.68 & 711.47 \\
\hline 3:00 PM & 919.23 & 576.15 & 755.33 & 659.35 & 863.58 & 700.02 & 944.95 & 774.09 \\
\hline 4:00 PM & 775.30 & 279.12 & 781.07 & 474.93 & 791.72 & 700.38 & 742.18 & 649.24 \\
\hline 5:00 PM & 639.62 & 174.30 & 509.17 & 370.37 & 550.60 & 576.35 & 466.22 & 469.52 \\
\hline 6:00 PM & 311.90 & 136.52 & 62.52 & 148.40 & 334.22 & 533.52 & 256.43 & 254.79 \\
\hline 7:00 PM & 178.83 & 58.88 & 37.15 & 64.15 & 139.60 & 112.77 & 243.27 & 119.24 \\
\hline 8:00 PM & 50.67 & 30.52 & 31.95 & 32.35 & 35.65 & 32.52 & 49.05 & 37.53 \\
\hline 9:00 PM & 28.85 & 29.18 & 29.32 & 29.32 & 29.17 & 29.15 & 28.97 & 29.14 \\
\hline 10:00 PM & 28.88 & 29.22 & 29.37 & 29.35 & 29.35 & 29.22 & 29.03 & 29.20 \\
\hline 11:00 PM & 28.80 & 29.35 & 29.45 & 29.17 & 29.20 & 29.20 & 29.15 & 29.19 \\
\hline 12:00 AM & 28.87 & 29.42 & 29.43 & 29.27 & 29.25 & 29.42 & 29.05 & 29.24 \\
\hline
\end{tabular}

Based on the hourly average, the daily average solar radiation where it is $400 \mathrm{~W} / \mathrm{m}^{2}$ and more is during the 7 hours of the sun hours is from $10.30 \mathrm{am}$ to $5.30 \mathrm{pm}$. Average solar radiation produced during this period is $612.39 \mathrm{~W} / \mathrm{m}^{2}$. Table 2 shows the ambient temperature data and its daily average;

TABLE III Ambient Temperature Data and its Daily Average

\begin{tabular}{|c|c|c|c|c|c|c|c|c|}
\hline \multicolumn{7}{|c|}{ Temperature $\left({ }^{\circ} \mathrm{C}\right)$} \\
\hline Time & Day 1 & Day 2 & Day 3 & Day 4 & Day 5 & Day 6 & Day 7 & $\begin{array}{c}\text { Average } \\
\text { according } \\
\text { to hour }\end{array}$ \\
\hline 1:00 AM & 22.99 & 25.79 & 23.82 & 24.96 & 23.81 & 25.59 & 24.35 & 24.47 \\
\hline 2:00 AM & 22.90 & 25.52 & 23.76 & 24.66 & 24.04 & 25.63 & 24.22 & 24.39 \\
\hline 3:00 AM & 23.06 & 25.32 & 23.92 & 24.55 & 24.17 & 25.45 & 24.15 & 24.37 \\
\hline 4:00 AM & 22.91 & 25.00 & 23.67 & 24.40 & 23.66 & 25.01 & 23.99 & 24.09 \\
\hline 5:00 AM & 22.72 & 24.76 & 23.14 & 23.91 & 23.45 & 24.77 & 23.75 & 23.79 \\
\hline 6:00 AM & 22.79 & 24.66 & 22.89 & 24.12 & 23.37 & 24.73 & 23.76 & 23.76 \\
\hline 7:00 AM & 22.54 & 24.62 & 22.85 & 23.92 & 23.40 & 24.57 & 23.39 & 23.61 \\
\hline 8:00 AM & 22.89 & 24.80 & 23.19 & 24.08 & 24.73 & 25.05 & 23.93 & 24.09 \\
\hline 9:00 AM & 25.09 & 34.33 & 25.35 & 25.27 & 35.04 & 26.57 & 31.82 & 29.06 \\
\hline 10:00 AM & 30.97 & 40.71 & 38.46 & 26.75 & 40.80 & 22.42 & 39.59 & 34.24 \\
\hline 11:00 AM & 37.49 & 39.33 & 41.61 & 33.19 & 43.64 & 22.48 & 41.39 & 37.02 \\
\hline 12:00 PM & 36.30 & 36.42 & 42.92 & 37.91 & 40.85 & 23.92 & 43.81 & 37.45 \\
\hline 1:00 PM & 36.20 & 39.55 & 42.21 & 40.31 & 36.06 & 30.55 & 40.59 & 37.93 \\
\hline 2:00 PM & 34.81 & 34.52 & 36.82 & 36.44 & 35.47 & 33.09 & 34.83 & 35.14 \\
\hline 3:00 PM & 33.95 & 33.30 & 35.26 & 33.61 & 33.67 & 33.15 & 34.70 & 33.95 \\
\hline 4:00 PM & 32.15 & 31.98 & 33.95 & 32.77 & 32.52 & 31.87 & 33.46 & 32.67 \\
\hline 5:00 PM & 31.62 & 30.73 & 32.92 & 31.55 & 31.93 & 30.17 & 32.50 & 31.63 \\
\hline 6:00 PM & 30.84 & 29.38 & 29.87 & 30.29 & 31.60 & 30.52 & 30.97 & 30.50 \\
\hline 7:00 PM & 29.84 & 26.40 & 26.98 & 28.80 & 30.18 & 28.42 & 30.22 & 28.69 \\
\hline 8:00 PM & 28.32 & 25.13 & 26.81 & 26.00 & 28.51 & 26.60 & 28.65 & 27.15 \\
\hline 9:00 PM & 27.35 & 23.78 & 26.24 & 24.84 & 27.65 & 25.68 & 27.56 & 26.15 \\
\hline 10:00 PM & 26.71 & 23.92 & 25.70 & 25.20 & 26.77 & 25.48 & 26.83 & 25.80 \\
\hline 11:00 PM & 26.44 & 23.80 & 25.18 & 24.74 & 26.44 & 25.04 & 25.94 & 25.37 \\
\hline 12:00 AM & 26.12 & 23.82 & 25.21 & 24.01 & 25.99 & 24.40 & 25.62 & 25.02 \\
\hline
\end{tabular}

Based on the sun hours hourly average, the daily sun hours average ambient temperature is $34.97^{\circ} \mathrm{C}$

Based on the average solar radiation of $612.39 \mathrm{~W} / \mathrm{m}^{2}$ and the daily average ambient temperature of $34.97^{\circ} \mathrm{C}$, the $\mathrm{P}-\mathrm{V}$ characteristic graph is shown in Figure 2;

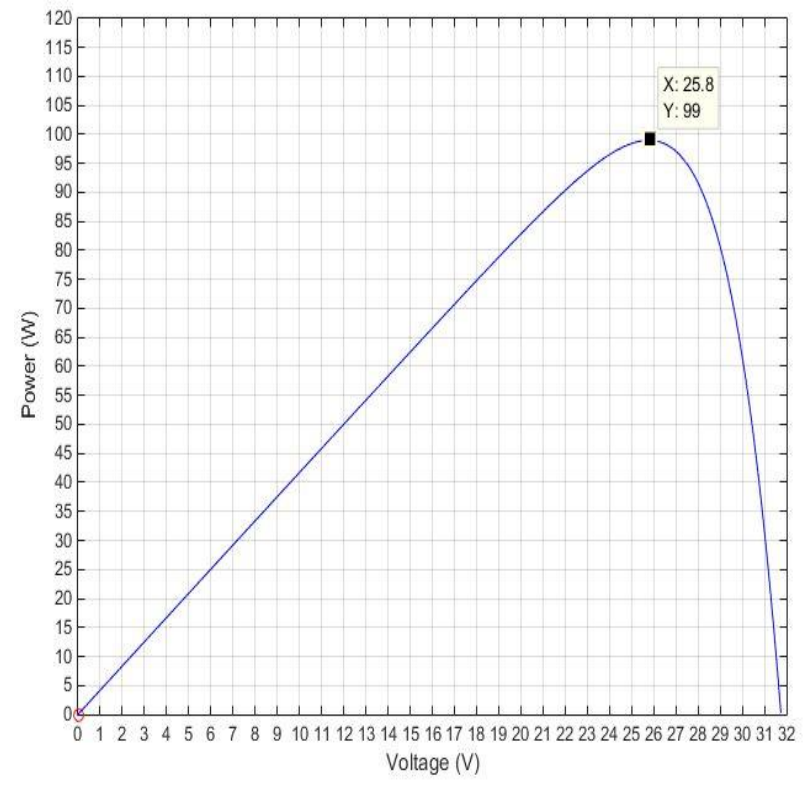

Fig. 2 P-V Characteristic Graph of Module.

Based on the P-V curve, the I-V curve is shown in Figure 3 ;

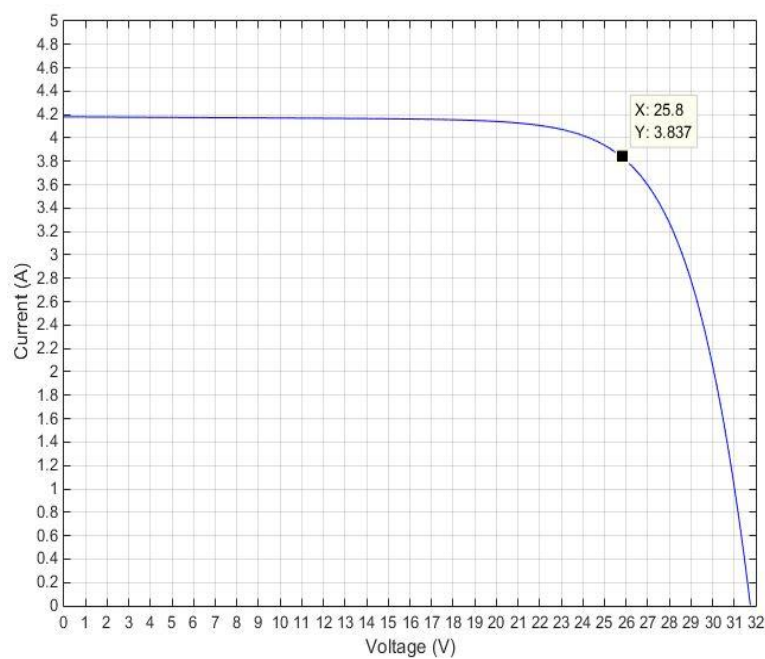

Fig. 3 I-V curve Characteristic Graph of Module.

When the peak voltage of $25.8 \mathrm{~V}$ is present through MPPT, the current will be 3.837A. Therefore, using Equation 1, a graph function can be found;

$$
\begin{aligned}
& 1200=\left(\mathrm{X}_{\text {series }}\right)(25.8)\left(\mathrm{Y}_{\text {parallel }}\right)(3.837) \\
& \mathrm{Y}_{\text {parallel }}=12.12 / \mathrm{X}_{\text {series }}
\end{aligned}
$$

The reciprocal function graph based on Equation 3 is shown in Figure 4 below; 


\section{International Journal of Innovative Research in Electrical, Electronics, Instrumentation and Control Engineering ISO 3297:2007 Certified \\ Vol. 4, Issue 10, October 2016}

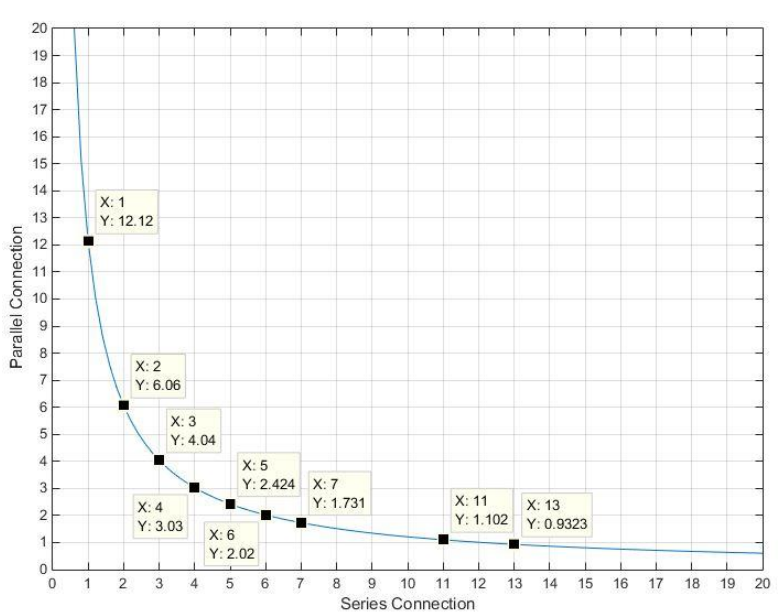

Fig. 4 Reciprocal Function Graph Based on Equation 3.

The voltage at the Grid is $240 \mathrm{~V}_{\mathrm{RMS}}$. Based on the modulation amplitude ratio of the inverter that is 1 , the input $\mathrm{V}_{\mathrm{dc}}$ of the inverter which is the output $\mathrm{V}_{\mathrm{dc}}$ of the converter must be $340 \mathrm{~V}$. Therefore, the input voltage of the boost converter must be not lesser than $25 \%$ of the output voltage that is $85 \mathrm{~V}$ due to the proper duty cycle of the boost converter to be 0.75 or lesser to ensure efficiency. [5]. The voltage produced by the PV array must be at the range of the boost converter input voltage that is at least $85 \mathrm{~V}$ due to the boost converter duty cycle limit through MPPT. The average solar radiation during the sun hour period gives $25.8 \mathrm{~V}$ per panel whereas the lowest solar radiation moment in the sun hour period produces 25 $\mathrm{V}$ per panel through MPPT. Both these voltage limits must satisfy the same series and parallel connection of the panels in order to be avoid higher costing and unwanted power generation. The maximum solar radiation during the sun hour period gives $26.1 \mathrm{~V}$ per panel. These voltage levels were however taken at the same temperature. Practically, a higher solar radiation will give a higher temperature which will reduce the generation power. In order to have more room if at all a condition exist where it is very sunny after a rainy early morning so that the temperature should be lower, the maximum generation based on maximum solar irradiation are taken at average temperature. The average solar radiation voltage is taken for overall system generation design whereas the lowest solar radiation voltage is ensure that it does not fall below the needed voltage to maintain the boost converter duty cycle.

Thus, the number of series-connected module must be;

Minimum number of series connected panels =

$\mathrm{V}_{\text {in-boost converter }} / \mathrm{V}_{\mathrm{PV} \text {-panel }}$

At maximum solar radiation;

Minimum series connected panels $=85 / 26.1=3: 26$

At average solar radiation;

Minimum series connected panels $=85 / 25.8=3: 29$

At lowest solar radiation;

Minimum series connected panels $=85 / 25=3: 4$
The number of series connected module must be 4 and above for all highest, average and lowest solar radiation. Based on the inverse function graph at Figure 4.12 above, the configuration of PV array are as following in Table 3.

TABLE IIII Configuration of PV Array

\begin{tabular}{|c|c|c|c|}
\hline Configuration & $\begin{array}{c}\text { Series } \\
\text { Connection }\end{array}$ & $\begin{array}{c}\text { Parallel } \\
\text { Connection }\end{array}$ & $\begin{array}{c}\text { Total } \\
\text { Panels }\end{array}$ \\
\hline 1 & 4 & 4 & $(4)(4)=16$ \\
\hline 2 & 5 & 3 & $(5)(3)=15$ \\
\hline 3 & 6 & 3 & $(6)(3)=18$ \\
\hline 4 & 7 & 2 & $(7)(2)=14$ \\
\hline 5 & 8 & 2 & $(8)(2)=16$ \\
\hline 6 & 9 & 2 & $(9)(2)=18$ \\
\hline 7 & 10 & 2 & $(10)(2)=20$ \\
\hline 8 & 11 & 2 & $(11)(2)=22$ \\
\hline 9 & 12 & 2 & $(12)(2)=24$ \\
\hline 10 & 13 & 1 & $(13)(1)=13$ \\
\hline
\end{tabular}

The least number of panels used is in configuration 10 which can also deliver the higher voltage than $85 \mathrm{~V}$ which eases boost converter connection, therefore, configuration 10 selected.

Since there are 13 series connected panel, PV array voltage output will be;

At minimum solar radiation;

$$
\left(\mathrm{V}_{\text {panel-min }}\right)\left(\text { Number }_{\text {series-connected }}\right)=\mathrm{V}_{\mathrm{PV} \text { - array }}
$$

$$
(25 \mathrm{~V})(13)=325 \mathrm{~V}
$$

At maximum solar radiation

$$
\left(\mathrm{V}_{\text {panel-max }}\right)\left(\text { Number }_{\text {series-connected }}\right)=\mathrm{V}_{\mathrm{PV} \text {-array }}
$$$$
(26.1 \mathrm{~V})(13)=339.3 \mathrm{~V}
$$

Therefore, PV array voltage output varies from $325 \mathrm{~V}$ to $339.3 \mathrm{~V}$ which is also directly links to the boost converter input voltage.

\section{IV.POWER PLANT COURSE OF OPERATION}

PV array is connected with the DC bus through a DC/DC boost converter, and afterward to the AC grid through a $\mathrm{DC} / \mathrm{AC}$ inverter. The inverter has its self-decision control objective (boost converter controls the PV generator to convey the greatest power conceivable and grid connected inverter control the real and reactive power at $\mathrm{AC}$ bus to be uniform). Keeping in mind the end goal to set up a legitimate working PV power plant, a boost chopper circuit is constantly utilized as the boost DC/DC converter. The DC/DC converter rises the low daylight based voltage to a proper level diverging from the required PV power using the MPPT technique. 


\section{IJIREEICE \\ International Journal of Innovative Research in Electrical, Electronics, Instrumentation and Control Engineering \\ ISO 3297:2007 Certified \\ Vol. 4, Issue 10, October 2016}

The yield of the DC/DC converter is then supplied to the inverter. The inverter is utilized to meander down and to change the yield voltage as demonstrated by the system voltage. The AC yield of the inverter regularly often accompanies the high-order harmonics by the PWM switching of the DC/AC converter. A capacitor is installed between PV array and the boost circuit, which is utilized to lessen high frequency harmonics and also as a capacitor bank to supply reactive power demand to keep up the power factor of the grid. Figure 5 shows the modelling of the power plant in MATLAB-Simulink;

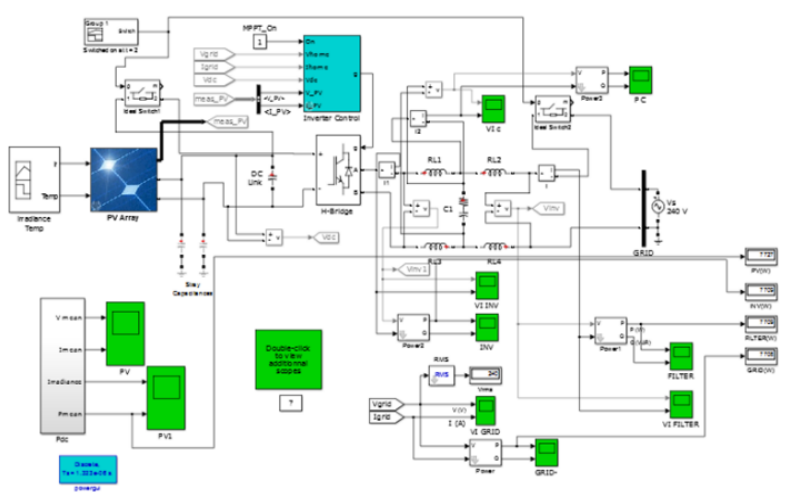

Fig. 5 MATLAB-Simulink modelling of the Power Plant

\section{SIMULATION AND RESULTS}

The solar radiation and weather pattern that was used in the simulation based on the average data acquired for a week from the weather station is shown in Figure 6 below;

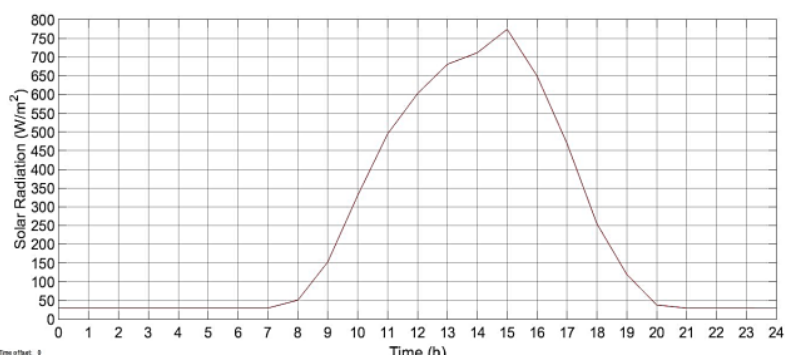

Fig. 6a Solar radiation pattern that is used in simulating the PV power plant.

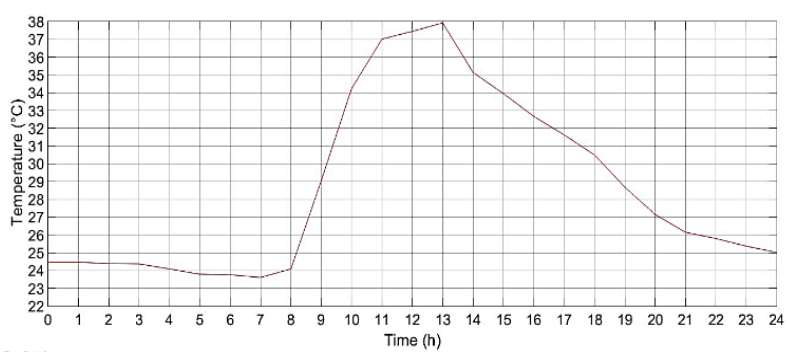

Fig. $6 \mathrm{~b}$ Temperature pattern that is used in simulating the PV power plant

The simulation output based on parameters above are shown in Figure 7 below.

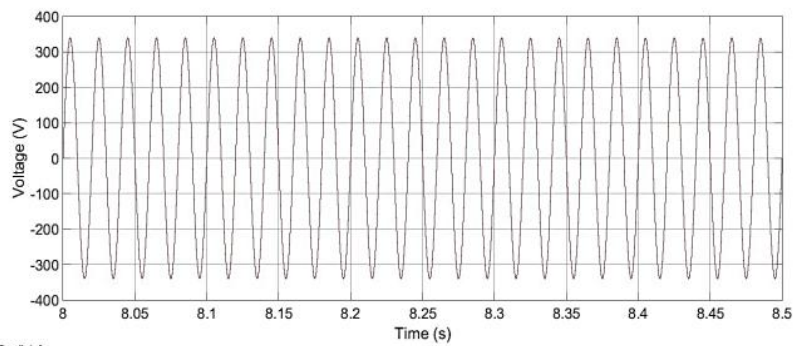

Fig 7a Uniform output AC voltage supplied to the grid.

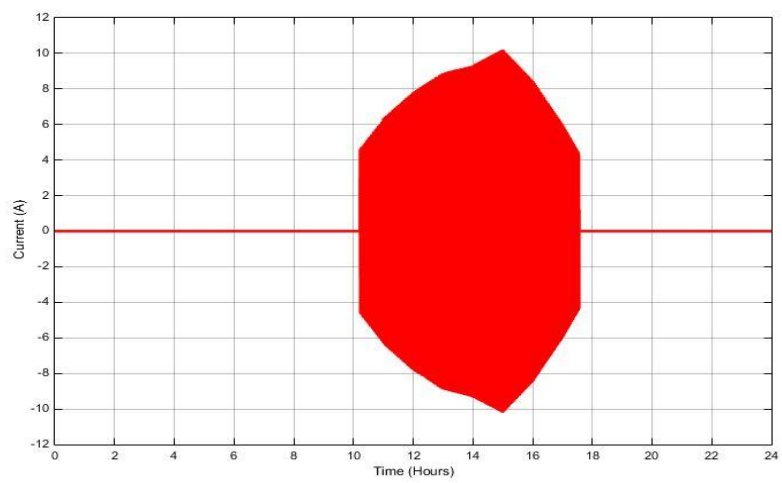

Fig $7 \mathrm{~b}$ Output AC current pattern of 24 hours supplied to the grid.

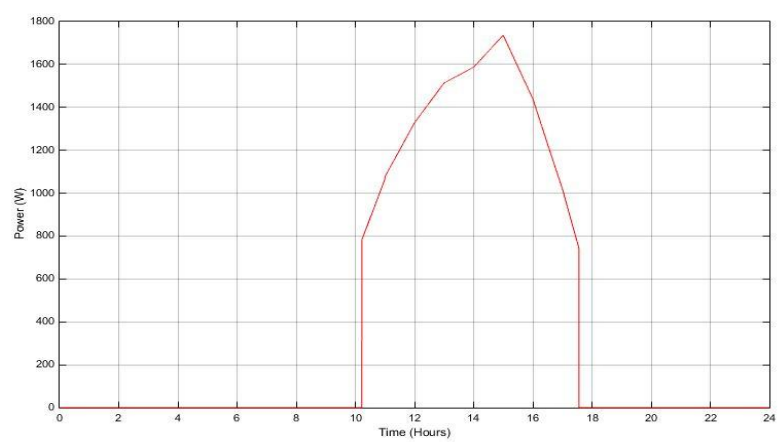

Fig 7c Output power generated for 24 hours supplied to the grid.

The total electrical energy generated a day is based on the graph is found by calculating the area under the curve using the trapezoidal method.

Total electrical energy generated

$$
=\sum_{n=0}^{23} \frac{\left(P_{n}+P_{n+1}\right) \times\left(t_{n+1}-t_{n}\right)}{2}
$$

Total electrical energy generated $=9.8 \mathrm{kWh}$

The generated electrical energy for a day is $16.7 \%$ more than required. This is the minimum amount that can be generated due to the minimum parallel connected PV array must be at least 13 modules. This is due to the voltage generated to be more than the grid voltage. The design will be accommodate two household energy usage if PV arrays are fixed at a slightly bigger magnitude. 


\section{IJIREEICE \\ International Journal of Innovative Research in Electrical, Electronics, Instrumentation and Control Engineering ISO 3297:2007 Certified \\ Vol. 4, Issue 10, October 2016}

\section{VI.CONCLUSION}

This paper introduced the planning, design and optimization technique for building up a single-phase gridconnected photovoltaic power plant in based of real world and time conditions for an unceasing operation. A particular yield objective was set which was the whole framework to have the capacity to generate no less than $8.4 \mathrm{kWh}$ a day of electrical energy. The yield anticipated at first was achieved in this paper which was effectively accomplished through the planning, designing and optimization strategy. Planning incorporates the sizing of the PV systems according to the environmental circumstances, weather and climate parameters and the power demand. The designing was finished by actualizing the suitable size of PV module and the MPPT technique for the control module with a specific end goal to fulfil the requirements of such a generated output. The entire generation process was specifically influenced by the environmental elements. The optimization was done with the needed calculation of connections for the PV module in order to achieve the needed output with the lowest number of panels. The determination of parameters for the control module further decreases the losses. This outcome guarantees that such a robust and efficient framework with high reliability and stability can be implemented.

\section{ACKNOWLEDGMENT}

A special thanks goes to the "Research University Grant (RUI) - RCMO, UnivesitiSains Malaysia with no. account: 1001/PELECT/81425 that has fully supported and funded this research and also thanks to Power Laboratories of School of Electric and Electronic Engineering - USM, that has provided the research facilities and equipment/instruments to carry out this research project.

\section{REFERENCES}

[1] LO, Y.-K., LEE, T.P., WU, K.H. Grid-Connected Photovoltaic System with Power Factor Correction. IEEE Transactions on Industrial Electronics, v. 55, n. 5, p. 2224-2227, May 2008

[2] J. Bratt, Grid Connected PV Inverters: Modelling and Simulation, Master of Science in Electrical Engineering, San Diego State University, 2011.

[3] KEY WORLD ENERGY STATISTICS, International Energy Agency, IEA. Printed in France by Chirat, November 2015.

[4] Cooling Appliances Uncool For Environment, June 29, 2012 16:02 PM, Malaysian National News Agency. Bernama.

[5] Serdarevic, E.Determining the Practical Limit for Boost Factor in DC-DC Voltage Conversion, Voltage Conversion, 2011.

\section{BIOGRAPHIES}

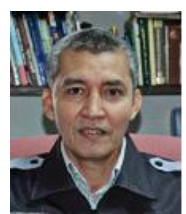

SyafrudinMasri received his Master Degree in Electrical Power Engineering and the Ph.D. degree from the Bandung Institute of Technology (ITB), Bandung, Indonesia, in 1993 and 2001 respectively.
$\mathrm{He}$ is currently an Associate Professor with the Department of Electrical and Electronic Engineering, Universiti Sains Malaysia (USM) of Malaysia. His research interests include electrical power quality, power electronic application, renewable energy, and electrical machine drives. $\mathrm{He}$ is member of IEEE Industry Applications Society.

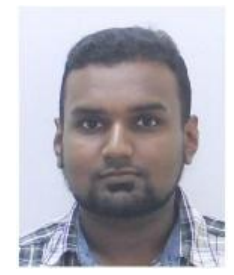

Paaventhan Raj received his Bachelor's Degree in Electrical Power Engineering with first class honours from Universiti Tenaga Nasional, Selangor, Malaysia in 2015. He is currently a Postgraduate in School of Electrical and Electronics Engineering, UniversitiSains Malaysia (USM), Malaysia. His research interest includes but not limited to grid connected solar powered electrical generation. He is a member of Institute of Engineers Malaysia (IEM), Board of Engineers Malaysia (BEM) and Young Engineers Society (YES). 